\title{
LNG development across Europe: infrastructural and regulatory analysis
}

by Susanna Dorigoni ${ }^{1}$ and Sergio Portatadino ${ }^{2}$

\begin{abstract}
In this paper a cross-section infrastructural and regulatory analysis of the European LNG sector is presented. The LNG chain is maintained as being a good tool to enlarge the number of natural gas exporters to Europe, adding in this way to competition and to the achievement of the targets of the liberalisation process, that is a decrease in price for final customers and security of supply. The main reason for this is to be identified in the minor specificity of the regasification plant related investment compared to pipeline transportation. The latter, in fact, brings about, once built, a physical tie between producers and importers that prevents the buyer from changing supplier, in order to recover the high fixed sunk costs connected with the pipeline investment, and effective competition from developing. A regasification terminal, on the contrary, is theoretically able to receive cargoes from whatever source of supply according to the relative conveniences. Nevertheless in order to develop its potential the LNG market needs to be well designed and regulated. More particularly, regulation is meant to play a key role in promoting regasification investments without hindering competition.
\end{abstract}

JEL CODES: L 50; L95; L $98 ;$ Q 41; Q 55;

\section{Introduction}

The liberalisation process affecting the natural gas market in Europe (COM/30/98 and COM/55/03) is aimed at reducing prices paid by final consumers and, contemporarily, ensuring improvements in quality of service and security of supply. These targets should be achieved by favouring the transition of the industry from a concentrated market to a competitive environment. According to the microeconomic theory, pure competition leads to the most efficient resource allocation. Competition, in fact, causes commercial firms to develop new products, services, and technologies. This

\footnotetext{
${ }^{1}$ IEFE, Università Bocconi, susanna.dorigoni@unibocconi.it

${ }^{2}$ IEFE, Università Bocconi, sergio.portatadino@unibocconi.it
} 
gives consumers greater selection and better products. The greater selection typically causes lower prices for the products compared to what the price would be if there was no competition (monopoly) or little competition (oligopoly). One of the fundamental condition for competition to develop is (among others) represented by the presence of a plurality on the supply side. Unfortunately the most part of the demanded gas in the European Union is imported, that is to say, produced outside the European border by a few number of supplier that do not compete among each other due to the rigidity of the pipeline transportation system. In other words the consumption market is separated from the production market which cannot be controlled. This means that competition (at least the one conceived by the economic theory) is by definition impossible to occur (unless the above mentioned situation does not change).Therefore, the European legislator has probably intended to promote competition among importers down the European border. Nevertheless, the reform process could lead to a fragmentation on the European importing side which might reduce the bargaining power of importers during the negotiations with non-European exporters ${ }^{3}$.

\section{The netback value pricing}

The outcome of the liberalization "revolution" could then be different from what expected: it is true that competition could lower margins afterwards import (from the European border to the final customer) but this could turn into an increase in exporting countries' income. In fact, foreign producers could take advantage of their bargaining power (a few exporters against an increasing number of importers) to raise gas prices and incorporate the positive effect of liberalization in the upstream phases. In other words, gas price could lower in the short run, but then raise afterwards because margins released by competition wouldn't go to final customers, but to producers.

The negotiation between producers and importers occurs in fact on the basis of the netback value of gas which is calculated as follows:

- Price of the cheapest alternative fuel (petroleum product)

- Minus cost of transporting gas from the border to the customer;

- Minus cost of storing gas to meeting the customer's demand fluctuations.

In this way the netback value can be defined as the maximum selling price of gas, should the latter be higher consumers would switch to the backstop fuel. In other words, the gas netback value is also the maximum price at which importers are willing to purchase it from producers in order to keep natural gas competitive with other fuels: at that price it would be in fact indifferent to use natural gas or any other substitute fuel.

There is also a minimum selling price of natural gas which consists in the price that allows the producer to cover extracting and transportation costs to the European border (the so called "cost plus value"). The difference between the

${ }^{3}$ On the theory of bargaining power see Galbraith, 1952. 
netback value and the cost plus value constitutes therefore a rent that is shared among exporters and importers according to their bargaining power.

The latter is likely to be reduced for European importers as a consequence of the introduction of competition which will lead to a rise in the number of operators and, therefore, to a decrease in the quantity individually purchased.

For instance in Italy, compared to a situation in which ENI was the sole importer, in a six years' period, the amount of importers has risen to almost 20 operators ${ }^{4}$, and, although, for the time being, the incumbent remains the main supplier (as it currently happens in the most of the European countries) it is to be expected that the situation will soon turn to a significant market fragmentation. This will therefore harm security of supply in terms of price.

In fact, security of supply -that is one of the main goal of the liberalisation process- can be conceived in two ways: with reference to the quantity, and with reference to the price. In other words, security of supply means that a sufficient quantity of gas should clear demand at convenient prices. Security of supply (price risk) is then becoming a very important issue whose neglect could compromise the main target of the reform: a decrease in price for final consumers. It is then becoming a priority to achieve a major degree of flexibility in the transport phase with the aim of diversifying the supply side in order to have a larger number of exporters available to clear demand, also making them compete among each other.

Figure 1: Netback value pricing

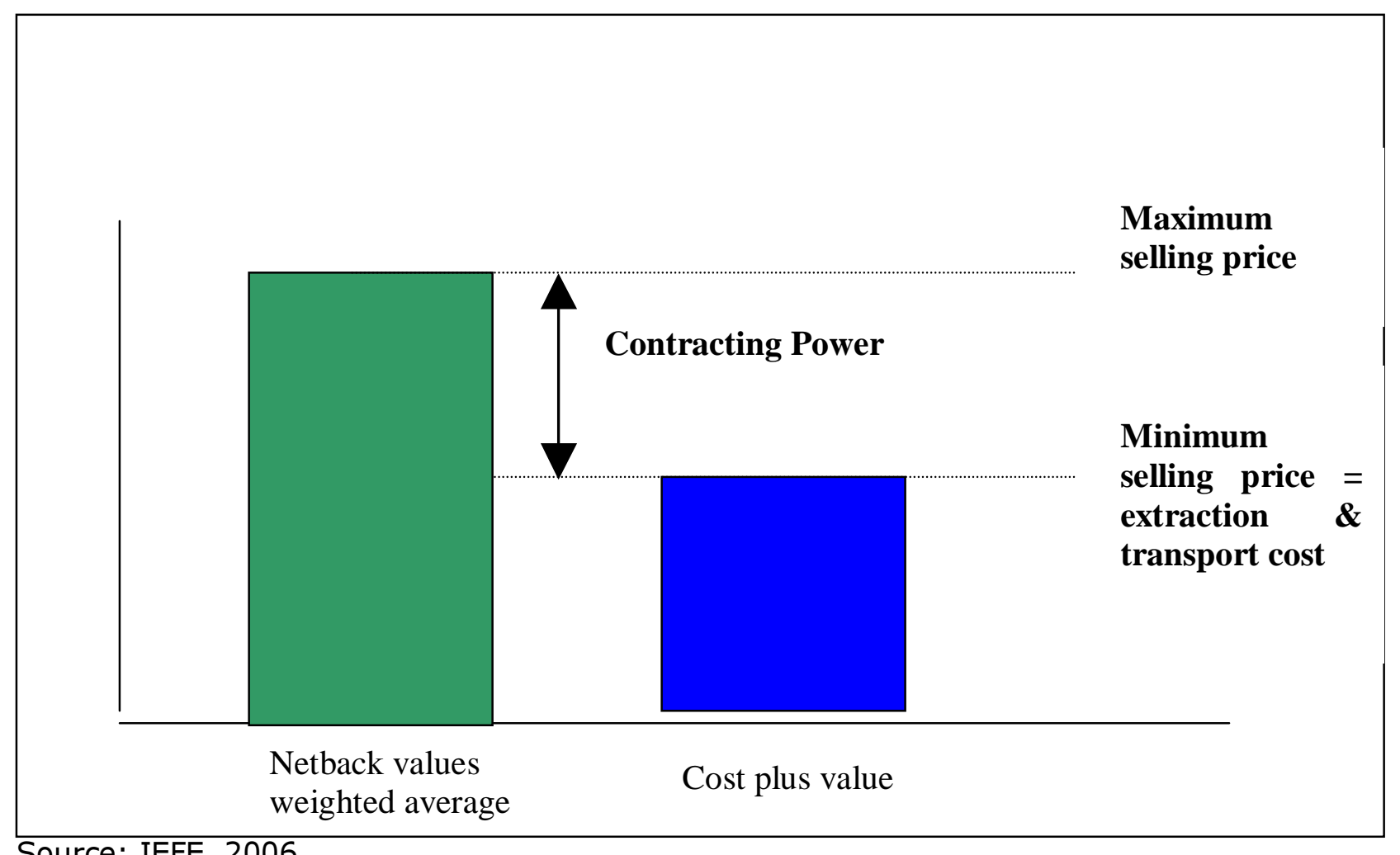

Source: IEFE, 2006.

\footnotetext{
${ }^{4}$ See AEEG, Relazione Annuale 2005.
} 


\section{LNG capabilities}

This target could be (at least partially) achieved by increasing the European regasification capacity for different kind of reasons:

1. The LNG chain is more flexible considering the fact that it allows a switch to a different seller according to the competitiveness among supplies. LNG infrastructures are less project-specific than pipelines, which is an incentive for new investments and calls for shorter contracts. In fact, Regasification Plants can receive ships coming basically from any Liquefaction Plant.

2. The technological innovation has lead to a significant decrease in LNG costs, making it possible to cover only a part of the relative investment with a take or pay contract. This would allow spot transactions across member states and lead to a globalisation of the whole market.

3. LNG allows for gas arbitrages among different markets through ship deviation.

4. LNG links only the producer and the consumer countries, without passing through foreign states which would ask for royalties and could even subtract large shares of gas transported by pipeline (see the "RussiaUkraine war of gas").

5. Given the need for shorter contracts or smaller load factors, the LNG chain allows the entrance on the market by new operators that would otherwise be unable to do so according to the absence of spare capacity on the existing pipelines, which remain throughout Europe under the national incumbents' control.

6. The possibility to enlarge the supply base and to switch to another seller would also reduce the exporter's contracting power balancing in this way the above mentioned decrease in the importers' bargaining power.

In the past this solution could be compromised on the basis of the excessive costs that the LNG chain would entail compared to the pipeline transportation; but recent technological developments have increased the competitiveness of LNG even on the short distances. Moreover, the necessity for traditional pipe exporters like Russia to start the development of expensive frontier-fields in order to cover exports and internal demand, could further help LNG competitiveness (considering the whole value chain) against imports by pipe. A part from economic considerations, as most of so far undeveloped gas reserves are located far away from European markets, and as European demand is likely to sharply increase, it is clear that LNG will play a key role to bring this gas to the market, when distance or natural and political obstacles make pipeline transport impossible. 
Moreover the growing supply of LNG, accompanied by the increased flexibility in LNG trade, which can physically be directed to the highest value market ${ }^{5}$, are adding to the security of gas supply. Contractual arrangements are also more flexible. Spot and flexible LNG purchases are increasingly used to cover part of peak gas demand. Even though a global gas or global LNG market may still be a long way off, LNG is already linking different markets together, by allowing shifting volumes between regions, benefiting from differences in their supply and demand balance. Indirectly this adds to market flexibility and integration.

There is growing recognition on the part of both producers and consumers of the increasing role of short-term and spot sales. These sales play a niche function to sell spare capacity on the producing side, and to complement longterm purchases for buyers. While long-term contracts will remain dominant in the foreseeable future, spot sales (which mean short-term deals or the sale of one cargo) are expected to take a growing share ${ }^{6}$. Also a more flexible approach to and a wider range of pricing mechanisms is emerging in the LNG industry: suppliers are adopting different pricing policies according to the buyers' market. For instance, Qatar, which sells in the four main LNG markets, has pegged its LNG sales to crude oil prices in Japan, to Henry Hub spot prices in the US, to NBP spot prices in the UK, and to fuel oil prices in continental Europe.

All these reasons make the LNG tool a good way of eliminating the trade-off between competition and security of supply (as far as price is concerned), as the numerous regasification projects undertaken by many operators in Europe are demonstrating. Reducing bargaining power of foreign producers, increasing the number of possible sources, subtracting part of gas margin to producers and diverting it to final consumers, are all objectives of the European liberalisation process which have not yet been achieved. The development of the LNG chain could lead to the completion of the reform process through the accomplishment of all these goals. European regulators could increase security of supply, in addition to market integration and competition, through the diversification of the supply side thanks to the development of a European LNG market.

In other words, within this context, regulation is meant to play a key role. The reference goes to the promotion of new investments, to the way in which capacity allocation on regasification terminals takes place, to the tariff practised for the usage of the plant. The development of the European LNG market should be well designed and supported by regulators in order to exploit LNG mentioned capabilities in the best way, and to foster competition among exporters. More particularly regulation should find the right balance between the promotion of new investments through proper incentives and the development of competition, which might represent a critical trade-off.

\footnotetext{
${ }^{5}$ Which is supposed to be the one in which the source is most needed.

${ }^{6}$ However, most experts agree that this development will not lead to large-scale trading as it happens in the oil market, with an extensive paper as well as physical market.
} 
After an analysis of the forecasted infrastructural developments in Europe that highlight, according to their specificities, LNG potentialities in terms of importing portfolio enlargement, a cross-section overview of regulation is presented, both with reference to the access to regasification terminals and to the promotion of investments.

\section{LNG developments in European countries}

In this section, data about European regasification terminals at various stages of authorization or completion are presented ${ }^{7}$. The following table summarizes the status of the European plants by country.

Table 1: Status of EU-25 regasification projects ${ }^{8}$ by country (2006)

\begin{tabular}{|c|c|c|c|c|c|}
\hline & & Existing & $\begin{array}{c}\text { Under } \\
\text { construction }\end{array}$ & Proposed & Total \\
\hline Country & Belgium & 1 & 1 & 0 & $\mathbf{2}$ \\
\hline & Cyprus & 0 & 0 & 1 & $\mathbf{1}$ \\
\hline & France & 2 & 1 & 3 & $\mathbf{6}$ \\
\hline & Germany & 0 & 0 & 1 & $\mathbf{1}$ \\
\hline & Greece & 1 & 1 & 2 & $\mathbf{4}$ \\
\hline & Ireland & 0 & 0 & 1 & $\mathbf{1 6}$ \\
\hline & Italy & 1 & 2 & 13 & $\mathbf{1}$ \\
\hline & Latvia & 0 & 0 & 1 & $\mathbf{3}$ \\
\hline & Netherlands & 0 & 0 & 3 & $\mathbf{1}$ \\
\hline & Poland & 0 & 0 & 1 & $\mathbf{1 4}$ \\
\hline & Portugal & 1 & 0 & 1 & $\mathbf{1}$ \\
\hline & Spain & 5 & 4 & 5 & $\mathbf{6 3}$ \\
\hline & Sweden & 0 & 0 & 1 & 6 \\
\hline
\end{tabular}

Source: IEFE, 2006

As it is possible to note from table 1 there are currently 12 terminals in Europe. The country that has historically most invested in the LNG chain is represented by Spain, followed by France.

12 terminals are also under construction with Spain on top of the list, followed by UK and Italy. It is then quite impressing the huge number of proposed plants which amounts to 39 .

The most of them are supposed to enter into operation in Italy, UK and Spain. Of course it is necessary to take into consideration the possibility that not all the terminals listed in the table will be effectively built according to the

\footnotetext{
7 The sources of these data are represented by GTE, Drewry Shipping Cousultants Limited and company/governments press releases available on the web. In most cases the mentioned data were checked through interviews with at least one operator involved in each terminal.
}

${ }^{8}$ Both greenfields and expansions. 
authorisation difficulties and delays that often affect the LNG industry, and to the often fierce local oppositions.

Table 2: Maximum capacity of EU-25 regasification terminals by country (2006)

\begin{tabular}{|c|c|c|c|c|c|}
\hline & Existing & $\begin{array}{c}\text { Under } \\
\text { construction }\end{array}$ & Total & Proposed \\
\hline Country & Belgium & 4,5 & 4,5 & 9,0 & - \\
\hline & Cyprus & - & - & - & 0,7 \\
\hline & France & 14,8 & 8,3 & 23,1 & 16,0 \\
\hline & Germany & - & - & - & 10,0 \\
\hline & Greece & 2,3 & 4,3 & 6,6 & n.a. \\
\hline & Ireland & - & - & - & n.a. \\
\hline & Italy & 3,5 & 16,0 & 19,5 & 84,2 \\
\hline & Latvia & - & - & - & n.a. \\
\hline & Netherlands & - & - & - & $>12,0$ \\
\hline & Poland & - & - & - & 3,0 \\
\hline & Portugal & 5,2 & - & 5,2 & 3,3 \\
\hline & Spain & 39,9 & 12,8 & 52,7 & $>9,6$ \\
\hline & Sweden & - & - & - & n.a. \\
\hline & UK & $\mathbf{4 , 6}$ & 26,5 & 31,1 & $>18,9$ \\
\hline Total & & $\mathbf{7 4 , 8}$ & $\mathbf{7 2 , 4}$ & $\mathbf{1 4 7 , 2}$ & - \\
\hline
\end{tabular}

Data in Bcm. Source: IEFE, 2006

As far as forecasted regasification capacity is concerned it is possible to notice that terminals under construction will add $72 \mathrm{Bcm}$ to already existing capacity leading to a total amount of almost $147 \mathrm{Bcm}$.

\subsection{Capacity allocation on European terminals and the widening of the supply side}

The above presented LNG terminals overview is useful insofar as it allows to collect information in order to assess eventual new trends in receiving plants ownership and utilisation.

As a matter of fact, capacity allocation/utilisation seems to be more interesting than plant ownership if considered that it is the operator that has access to the terminal that is actually able to compete on the final market rather than the mere owner of the infrastructure.

Nevertheless also from ownership it is possible to make remarkable comments and observations, especially when data on capacity reservation are not available (and this is the case of planned terminals).

Given this, we will now present an infrastructural analysis whose main logic assumptions sound as follows:

- The exclusive presence of national incumbent operators on existing, under construction and planned terminals indicates that there is no competition at the border; 
- On the contrary, the utilisation of national terminals by firms other than the national incumbent means a certain level of competition at the national (if the third entrant is not foreign) or at the international (if the third party is not national) level, contributing in the latter case to market integration;

- The direct presence of non-European producers, both in the ownership and in the reservation of capacity at a terminal, reveals a new strategy on the production side:

- A strategy of direct penetration on the final or wholesale market when the capacity is used (downstream integration);

- A simple "control" strategy (midstream integration) when producers participate in the shareholding of the regasification plant which could sooner or later turn into direct downstream integration.

That is why we consider the ownership analysis particularly interesting with reference to non-European producers.

\subsubsection{Existing terminals}

Let us start from existing terminals ${ }^{9}$. In this case the ownership issue is not addressed considering that just in one case (Sagunto terminal in Spain), as far as producers involvement is concerned, it is possible to notice a very small participation by the Oman Oil Company.

As regards existing terminals, we can dispose of complete information, that is to say data for the whole available capacity, which amounts to almost $75 \mathrm{Bcm}$. The majority $(73 \%)$ of existing capacity is used by national incumbents, that is to say by incumbents in their country.

$21 \%$ of existing capacity is prerogative of other national operators, that is to say firms that compete with the incumbent within the same member state, (both of them belonging to the considered member state), which indicates a certain degree of intra-state competition.

The remaining $6 \%$ is used by non-European producers, namely Qatar and Algeria, almost with the same share.

\footnotetext{
9 Please note that the categories reported in the graph relating to existing terminals are different from the ones relating to terminals under construction because of the fact that nonEuropean Producers, national incumbents and other national operators are the only type of operators present on the existing terminals.
} 
Figure 2: Allocation of capacity on existing European regasification terminals (75 $\mathrm{Bcm})$

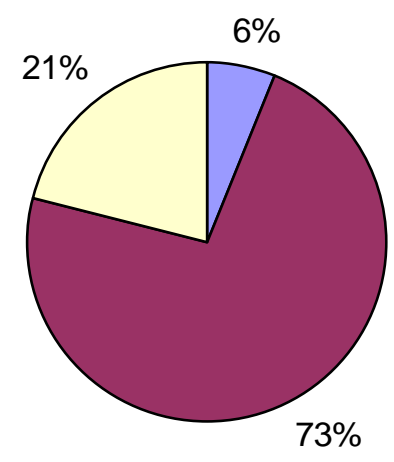

$\square$ non-European producers

$\square$ national incumbents

口other national operators

Source: IEFE, 2006.

There are not foreign operators competing on domestic markets (that is foreign firms other than the national incumbent competing with it in its country of origin).

\subsubsection{Terminals under construction}

As far as terminals under construction is concerned, it is worth specifying that data were available just for 9 terminals ${ }^{10}$ out of 12 , that account for a capacity equal to $63 \mathrm{Bcm}$ (87\% of total capacity under construction).

It is here interesting to highlight the new tendency in plants ownership by nonEuropean producers that currently hold shares for the $17 \%$ of the terminals analysed $^{11}$.

It is worth thinking of this fact in depth, considering that this strategy could affect the features of long term take or pay contracts that are maintained as being the principle reason for market pre-emption and vertical foreclosure in the European natural gas industry: the possibility of gaining control of the final market through participation in regasification plants ownership by the exporters could make them less keen on the extent of take or pay clauses and on the contract duration.

\footnotetext{
${ }^{10}$ Zeebrugge, Fos Cavaou, Revithoussa, Isola di Porto Levante, Brindisi, El Ferrol, Dragon LNG, Grain LNG, South Hook LNG.

${ }^{11}$ Participation in ownership is calculated according to the share held by different operators in the capital of the firm that is the regasification plant owner (referred to as "shareholders" in the plants charts) and not in terms of capacity.
} 
The remaining $83 \%$ is owned by European importers, namely national incumbents (almost 50\%), but also national or international operators other than national incumbents.

Figure 3: Ownership of European regasification plants under construction

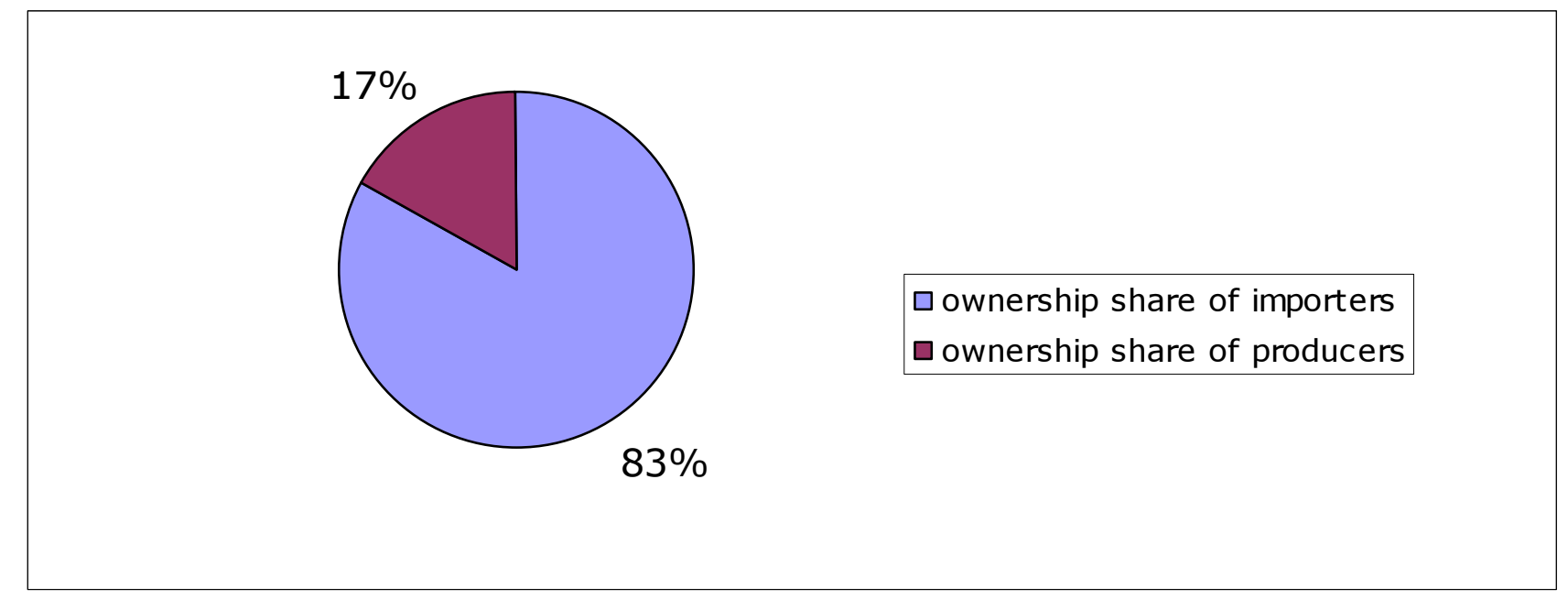

Source: IEFE, 2006.

Figure 4: Allocation of capacity on European terminals under construction (63 $\mathrm{BCm}$ )

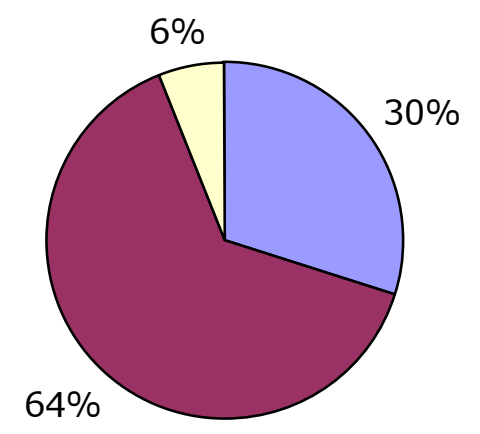

$\square$ national gas incumbents

$\square$ operators different form national gas incumbent

$\square$ free capacity for regulated TPA

Source: IEFE, 2006.

As far as allocation of capacity is concerned, it is possible to note a striking fact: the amount of capacity controlled by national incumbents has decreased to $30 \%$ of total under construction capacity ( $73 \%$ on existing terminals as seen before), while the $64 \%$ will be held by operators different from national gas incumbents. 
Only the remaining $6 \%$ is represented by free capacity to be assigned through TPA regulation (just in Italy).

It can be interesting to analyse the capacity held by firms that are not gas incumbents in the country where they have capacity at their disposal (intrastate or inter-state competition).

Figure 5: Allocation of capacity on European regasification plants under construction to operators different from national incumbents (41 $\mathrm{Bcm})$

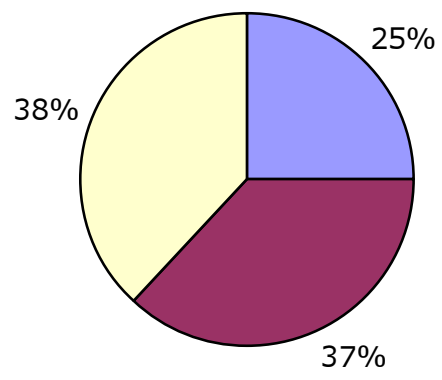

Source: IEFE, 2006.

As far as allocation on plants under construction to operators different from national incumbents is concerned, the above mentioned tendency is confirmed:

- $38 \%$ of this capacity is in fact allocated among non-European producers that are trying to gain direct access on downstream markets.

- $37 \%$ is held by foreign operators (inter-state competition), and

- the remaining $25 \%$ will be used by national competitors (intra-state competition).

Let's try to further split this outcome by considering the three categories distinctly.

Figure 6: Allocation of capacity among foreign operators (15 Gmc) 


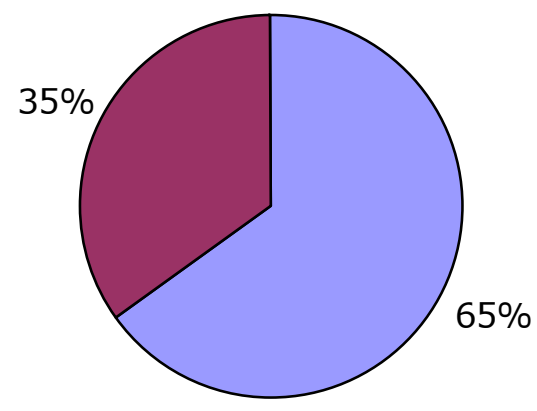

$\square$ European gas incumbents $\square$ other foreign competitors

Source: IEFE, 2006.

Let's start from capacity held by foreign operators: in the majority of cases (65\%) they are represented by European gas incumbents (operating, in this case outside their national boundaries). A clear tendency towards a European gas oligopoly is here outlined, but this fact could be appreciated if considering the limited plurality on the exporters' side and their bargaining power.

The remaining $35 \%$ will be used by other competitors, namely Exxon-Mobil in Italy and UK.

Figure 7: Allocation of capacity among national operators (10 Gmc)

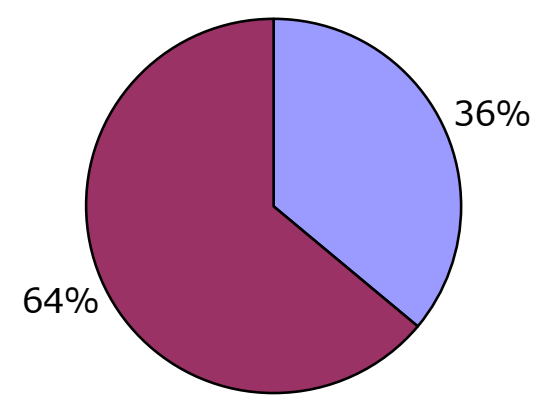

national incumbents on the electricity market

$\square$ other national competitors

Source: IEFE, 2006

National operators different from gas incumbents are represented by national incumbents on the electricity market or by other national competitors.

The first category will hold the $36 \%$ of this capacity: it is the case of Union Fenosa and Endesa in Spain. The remaining will be used by national gas operators that are not incumbent in their native market, such as Edison in Italy, or by other large firms operating in other energy markets such as Total in France, or Hellenic Petroleum in Greece. 
Finally, as far as allocation of capacity among non-European producers is concerned, it is possible to notice the major involvement of Qatar, Algeria and Malaysia.

Figure 8: Allocation of capacity among non-European producers (16 Bmc)

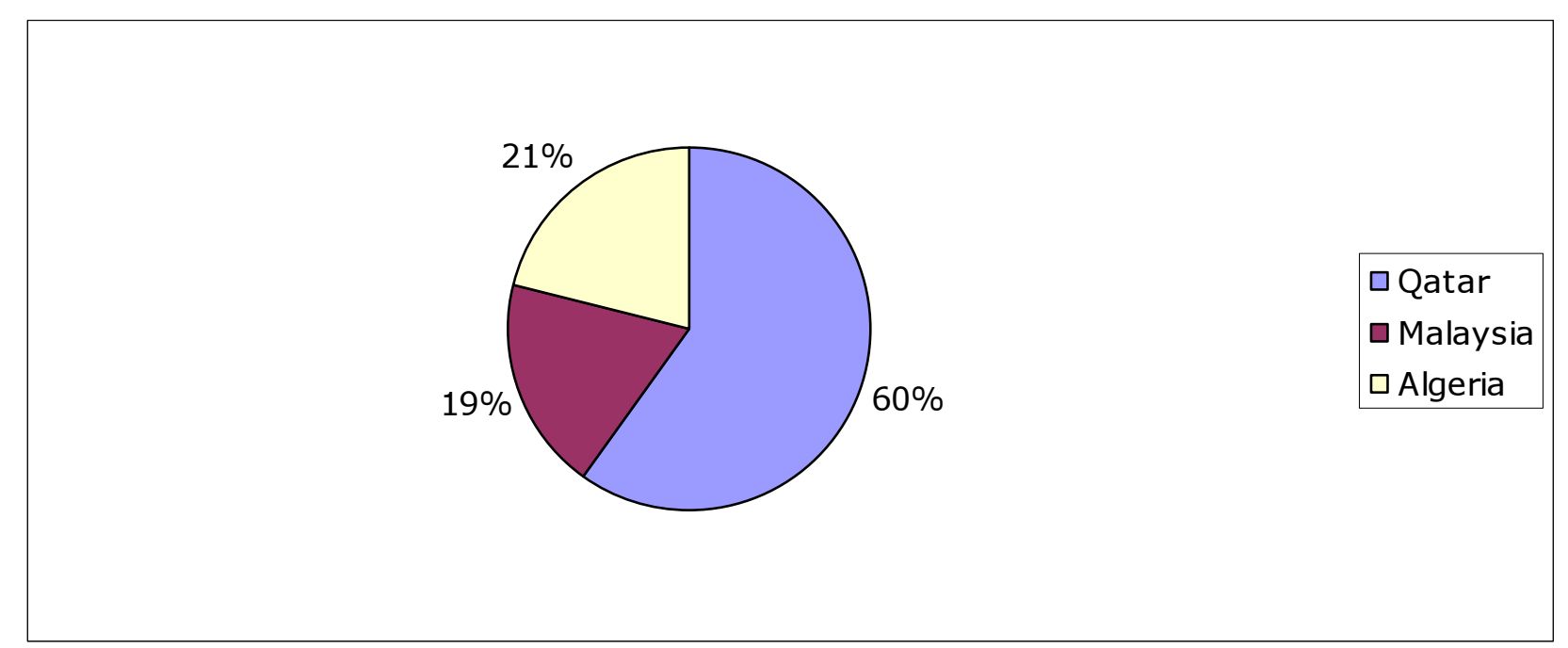

Source: IEFE, 2006

\subsubsection{Planned terminals}

Figure 9: Ownership of planned European LNG receiving terminals ${ }^{12}$

12 Data available for 30 planned terminals out of 39. 


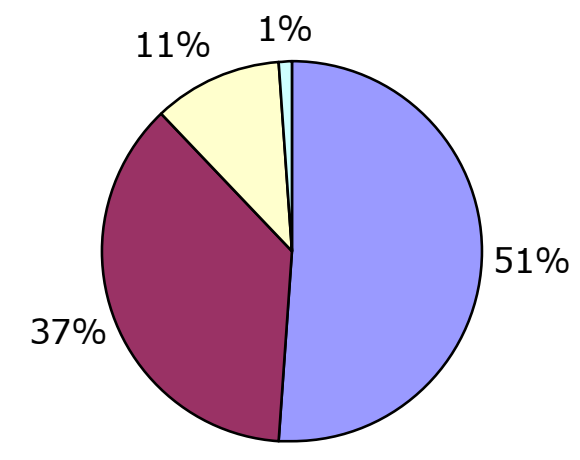

$\square$ national operators different from incumbent

$\square$ foreign competitors

$\square$ national incumbents

$\square$ producers

Source: IEFE, 2006

For planned terminals we do not have any data on reservation of capacity at our disposal: the only information we provide is, therefore, represented by shares in ownership.

The $99 \%$ of ownership is held by importers while producers own just the $1 \%$ of planned LNG receiving terminals.

A $37 \%$ participation to LNG capital is held by foreign competitors both European and non (such as Japanese and American companies), which adds to inter-state competition.

National operators other than national incumbents will compete with a $51 \%$ share, and national incumbents will hold the $11 \%$ of invested capital.

It is possible to conclude that, since ownership is very likely to turn into capacity reservation, the previously outlined tendencies seem (at least partially) to be confirmed, and that the construction of new LNG infrastructure is favouring market integration and competition within the European gas sector.

\section{LNG regulation in Europe (access rules)}

As mentioned before, to exploit the outlined LNG potentiality in terms of favouring competition, also beyond what previously shown, that is to say according to the possibility for new comers to gain access to terminals in case of available or unused capacity, even on the basis of spot transactions, the role of regulation seems to be crucial.

Access rules to an LNG facility mainly consist in:

- Tariff methodology.

- Capacity allocation.

The main targets of the EU liberalisation process were mostly concerned with an increase in competition but also with security of supply. 
As far as access rules to an LNG facility is concerned, the goal of competition seems, at first sight, to deal with capacity allocation mechanism rather than with tariffs paid for the regasification service, while security of supply is meant to be granted through the access charge which is supposed to assure the regasification plant owner a fair return on capital in order not to discourage future investments.

Nevertheless there is one aspect of the tariff methodology which is extremely important in favouring competition: the tariff design - fixed vs. variable components - rather than the total amount of it. This issue will be discussed below.

\subsection{Regasification tariffs in Europe}

From the reading of the European Directives ${ }^{13}$, aimed at creating a single and competitive market for natural gas in Europe, it is possible to clearly infer several principles that transport access prices should comply with in order to achieve the above mentioned target.

These principles can be summarised as follows:

- Allocative efficiency;

- Productive efficiency (X-efficiency);

- Dynamic efficiency;

- Fairness;

- Simplicity;

- Full cost recovery.

Let us explain the meaning of each criterion:

- Allocative efficiency is one of the most important features of neoclassical economics: it allows for a greater adherence of prices to long run marginal costs, which means that every user (shipper) is charged with a price based on its cost responsibility and it is, therefore, not discriminated as requested by the European Directive.

\footnotetext{
13 Among the principles underlying the Directive 98/30, those with the most significant implications for open access and cross-border trade include the principle of non-discrimination, the goal of establishing a competitive natural gas market, and the promotion of interconnection and interoperability. The Directive repeatedly invokes the principle of nondiscrimination, applying it to areas including: Member States' authorisation procedures (Articles 3, 4 and 5); Transmission, Storage and LNG (Article 7); Distribution and Supply (Article 10); and Access to the System (Articles 14, 20). It is also implicit in the other principles identified above, since discrimination is incompatible with a competitive natural gas market, and creates barriers to interconnection and interoperability. The principle of nondiscrimination affects many aspects of the Directive's implementation, and has special significance because of the structure of the natural gas industry in Europe.
} 
- $X$ efficiency identifies the ability of companies to reduce their costs, given a certain technology and productive organisation. This goal may also be achieved through price-cap devices.

- Dynamic efficiency has been revaluated only in the last years. It refers to the ability of introducing innovations (of product, process, organisation, etc.) which represent new opportunities for remarkable reduction of costs able to increase companies' competitiveness. It differs from $X$ efficiency since in the previous case cost reductions are introduced "under the same technology", while in the latter case efficiency gains arise from the introduction of innovations.

- Fairness is an extremely critical issue: it requires to go beyond the mere verification of a correspondence between price and cost-responsibility of every single user which is already implicit in the concept of allocative efficiency. A price system can be considered as fair if it discriminates on the basis of the of elasticity of demand. That is to say that consumers with rigid demand should pay less considering the fact that they are not able to change consumption patterns (fuel-switching) in order to minimise supply costs.

- Simplicity does not require particular consideration: tariffs should only be easily understandable, especially for those users' categories which have difficulties in finding information without high transaction costs.

- Full cost recovery means that the participation tie of the transport company has to be respected. In other words in case the transport service should not be supplied for non-sustainability, this would yield the worst result under the allocative point of view.

As it is possible to notice from the given explanations, every concept is different but fundamental in an open market environment.

Allocative efficiency is synonym of non-discrimination and, therefore, of competition: it ensures that all the involved subjects act on a level playing field.

X-efficiency and Dynamic efficiency lead to cost reduction and the decrease in price for final consumers allows to achieve one of the main goals of liberalisation. More particularly, dynamic efficiency is a very important issue with respect to security of supply (another target of the reform process) insofar as it implies the rationalisation of consumption by means of technological development.

Fairness is an issue related to certain categories of consumers rather than others. The fact that some users cannot benefit from inter-fuel competition implies their protection. Moreover, under a theoretical point of view, competition occurs both on the supply and the demand side: there has to be a plurality of supplier, but also the traded product should have substitutes.

Simplicity means that market rules are transparent, being this one of the main concern of regulators, and full cost recovery is necessary in order to grant that the service is offered, and the way in which costs are recovered should prevent the monopolist to earn extra-rents and to be, therefore, in a privileged position compared to other competitors. 
Some of the above mentioned principles have also been explicitly recalled by several interlocutors involved in the liberalisation process.

The Brattle Group ${ }^{14}$, well-known Commission consultants, indicate the following targets tariff methodologies should enable to reach for the improvement of the reform process:

- Non-discrimination;

- Competition;

- Promotion of interconnection between member states.

The first principle is the condition for the others: discrimination is inconsistent with competition and brings about barriers to cross-border transactions. It is here important to notice that non-discrimination in access charges means that every user should pay the cost generated by its use of the network. In other words non-discrimination is related to cost-reflectiveness and, therefore, to allocative efficiency. Promotion of interconnection depends also on the recovery, by the network owner, of the full cost it has incurred for managing the service, be it fixed or variable. That is why full cost recovery is one of the main principle a tariff mechanism should follow.

In the Bergognoux report (2001) objectives that access charges should pursue are also mentioned as follows:

- Cost-reflectivity;

- Simplicity;

- Promotion of interconnection;

- Full cost recovery;

- Promotion of the creation of a secondary capacity market;

- Providing the market with correct signals on investments.

Since we have already talked about the first four criteria ${ }^{15}$ let's focus the attention on the last two. The development of a liquid secondary market for capacity rights mainly depends upon the capacity allocation and conferment mechanism: we will therefore discuss this issue in the dedicated section ( $\S$ 5.2).

As far as the matter of supplying the market with correct scarcity signals is concerned, it is once again necessary to refer to cost-reflectivity in the sense that insofar as access charges correspond to the actual costs generated on the system they are able to give proper market signals to the community of users on the network. This leads us back to the concept of non-discrimination and allocative efficiency.

14 The Brattle Group, Methodologies for establishing national and cross-border systems of pricing of access to the gas system in Europe, London, 2000; The Brattle Group, C. Lapuerta, B. Moselle, Convergence of non discriminatory tariffs and congestion management systems in the European Gas sector, London, 2002, (pages 36-37).

15 Being the promotion of interconnection directly connected with the investments full recovery. 
Last but not least, also the $\operatorname{CEER}^{16}$ ( $6^{\text {th }}$ Madrid Forum) has indicated the purposes access charges should achieve in this way:

- Cost-reflectiveness;

- Full cost recovery;

- Correct market signals;

- Simplicity/transparency;

- Competition.

At this point we think we are allowed to consider the first list of tariff principles as exhaustive.

Given this, we will verify the way in which these principles are fulfilled by different tariff methodologies. In particular we will first consider the purpose of full cost recovery, which mostly depends on the way the Regulatory Asset Base (RAB) is calculated, and then, in a group, the other five criterion whose respect is connected with the structure of the access charge.

Table 3: Access charges for LNG terminals in Europe

\begin{tabular}{|l|l|l|l|}
\hline & RAB calculation & WACC & Tariff structure \\
\hline Belgium & $\begin{array}{l}\text { Reconstruction } \\
\text { costs }\end{array}$ & $7,1 \%$ & Capacity/commodity \\
\hline France & $\begin{array}{l}\text { Revaluated } \\
\text { historic costs }\end{array}$ & $\begin{array}{l}9,75 \% \text { before } \\
2004 \\
11 \% \text { after }\end{array}$ & Capacity/commodity \\
\hline Italy & $\begin{array}{l}\text { Revaluated } \\
\text { historic costs }\end{array}$ & $7,6 \%$ & Capacity/commodity \\
\hline Spain & $\begin{array}{l}\text { Revaluated } \\
\text { historic costs }\end{array}$ & $6,51 \%$ & Capacity/commodity \\
\hline UK & \multicolumn{3}{|c|}{ EXEMPTION } \\
\hline
\end{tabular}

Source: National Regulatory Authorities.

As it is possible to see from table 1 the basic method to calculate the Regulatory Asset Base (RAB) is a cost-plus system in which all the costs reported in the balance sheet of the company are covered by the tariff. This methodology is mainly aimed at favouring all the necessary investments on the grid to the extent that every capital expenditure is included in the tariff setting, and at respecting the participation tie of the transport company. In this sense the principle of full cost recovery seems here to be fully fulfilled. The only exception is represented by Belgium where a reconstruction cost is recognised.

${ }^{16}$ Council of European Energy Regulators. 
The latter could be lower than historic costs considering the dramatic technological innovations that affected the LNG chain, although mainly liquefaction and shipping activities.

The return on capital varies among the considered countries but if Belgium, France, Italy and Spain show a rate comprised between 6,51 and $7,6 \%$, in France the WACC (Weighted Average Cost of Capital) is equal to $9,75 \%$ for facilities entered into operation before year 2004 and to $11 \%$ thereafter. The aim of the regulator is clearly the one of boosting new investments considering the expected growth in natural gas demand.

\subsubsection{Access charges and efficiency}

As said before it is possible to maintain that capacity allocation mechanisms are more concerned with competition at the regasification plant level than tariffs. But also the achievement of a non-discriminatory (among other goals) access by third parties could depend on tariff design.

More particularly the reference goes to one part tariffs versus non-linear tariffs.

Optimal pricing for access to essential facilities has received considerable attention in recent years both from economists and policy makers throughout the world ${ }^{17}$. This has focused mostly on network utilities. Recent interest has been driven in part by the wave of privatisations of network utilities around the world and the international drive to open up network markets.

One of the most common access problems arises in networks where a service requires two legs, one a monopoly owned essential facility, and the other a potentially competitive segment. Suppliers other than the owner of the essential facility need to interconnect with the monopoly supplier and will generally be expected to contribute to the cost of the essential facility. The appropriate structure of this access charge has been the focus of significant debate within the economic theory.

Complex theoretical contributions deliver one message: the access charge is often performing too many tasks.

Different goals and policy objectives lead to alternative ways of calculating optimal charges.

While it is true that theory is extremely useful to understand the mediating function of access prices, one first fundamental step should precede any access distortion: whenever possible, the use of access pricing as an instrument for the promotion of too many goals should be avoided and other instruments should be used.

Nevertheless if considering the sole goal of increasing competition, or, at least, the latter as the main issue in our analysis, it is possible to maintain that the main feature a tariff structure should have in order to promote entry to the market is the one of being non-discriminatory.

17 See Kessides, 2004; Dorigoni, 2004; CEER, 2002; Crew, 2002; but also Katz, 1983; Schmalensee, 1981; Spence, 1977; Oi, 1971. 
This means that every operator should be charged the cost its access to the essential facility effectively brings about. In other words, access charges should be cost-reflective (which means allocative efficiency).

That is why we will consider this criterion as the most important one in evaluating the capacity of tariffs in ensuring the achievement of the liberalisation targets, even though, as highlighted before, all the mentioned principles seem to be definitely correlated.

Other goals a tariff structure should achieve (as specified before) should be $\mathrm{x}$ efficiency, in order to assure a decrease in service price, dynamic efficiency, in order to grant technological development, and also, simplicity and fairness.

We will now test the attitude of different tariff types in pursuing the above mentioned goals.

Table 4: Possible tariff structures, efficiency and effectiveness

\begin{tabular}{|l|c|c|c|c|c|}
\hline Type of tariff & $\begin{array}{c}\text { Allocative } \\
\text { Efficiency } \\
\text { non- } \\
\text { discrimination }\end{array}$ & $\begin{array}{c}\text { Productive } \\
\text { Efficiency }\end{array}$ & $\begin{array}{c}\text { Dynamic } \\
\text { Efficiency }\end{array}$ & Fairness & Simplicity \\
\hline $\begin{array}{l}\text { Monomial } \\
\text { (Fixed price) }\end{array}$ & $\bullet$ & $\bullet$ & $\bullet$ & $\bullet$ & $\cdots$ \\
\hline $\begin{array}{l}\text { Monomial } \\
\text { (Demand } \\
\text { based) }\end{array}$ & $\bullet$ & $\bullet$ & $\bullet$ & $\bullet$ & $\bullet$ \\
\hline $\begin{array}{l}\text { Binomial } \\
\text { (Usage based) }\end{array}$ & $\ldots$ & $\bullet$ & $\bullet$ & $\cdots$ & $\bullet$ \\
\hline $\begin{array}{l}\text { Monomial } \\
\text { (Energy based) }\end{array}$ & $\bullet$ & $\bullet$ & $\bullet$ & $\cdots$ & $\bullet$ \\
\hline
\end{tabular}

$\bullet \bullet$ high; • medium; • low.

Source: IEFE, 2006.

The frame which rises from the proposed considerations, and that is summarised in table 4 , is consistent with the initial assumptions. The number of goals pursued by the regulator and their eventual incompatibility make it hard for regulators to choose the optimum tariff structure: deciding to pursue 
a specific goal may signify to give up, at least partially, other objectives. In these cases, lacking a priority scale, it is reasonable to rely upon the theoretical consistency, eventually admitting a partial and limited shifting from it in order to be able to reconcile different goals. In particular, this means designing a polynomial tariff which represents the most balanced solution, leaving the definition of the relative weight of the different components to objective considerations about the nature of costs.

Table 5: Capacity/Commodity split in tariff determination in European countries

\begin{tabular}{|c|c|c|c|}
\hline Country & Capacity share & $\begin{array}{c}\text { Commodity } \\
\text { share }\end{array}$ & $\begin{array}{c}\text { Efficiency gain } \\
\text { factor }\end{array}$ \\
\hline Belgium & $100 \% 18$ & $0 \%$ & No \\
\hline France & $80 \%$ & $20 \%$ & No \\
\hline Italy & $80 \%$ & $20 \%$ & $1,5 \%$ of RAB \\
\hline Spain & $90 \%$ & $10 \%$ & $\begin{array}{c}15 \% \text { of the } \\
\text { inflation rate }\end{array}$ \\
\hline UK & n.a. & n.a. & n.a. \\
\hline
\end{tabular}

Source: IEFE's elaboration on national authorities' data, 2006.

Almost all the considered countries have adopted two-part tariffs in order to balance the so far described targets. Just in Belgium the tariff seems to be mainly concerned with fixed costs considering that no charge related to consumption has been introduced. In the UK tariff setting is free and, for this reason, it has not been possible to infer at least the average split between commodity and capacity charge.

The weights that have been given to the different parts are slightly different but they seem to converge on the actual cost structure of the natural gas transportation highly dominated by the presence of fixed costs.

This fact is of paramount importance since cost-adherence enables the access charge to provide appropriate scarcity signals to network users, and therefore, to arrange timely and proper investments if necessary.

\subsection{Capacity allocation on LNG terminals}

Table 6: Capacity allocation on LNG terminals in Europe: Belgium, France, Italy, Spain and UK

\begin{tabular}{|l|c|c|c|c|c|}
\hline Country & $\begin{array}{c}\text { Capacity } \\
\text { allocation }\end{array}$ & $\begin{array}{c}\text { Anti- } \\
\text { hoarding } \\
\text { clauses }\end{array}$ & $\begin{array}{c}\text { Antitrust } \\
\text { ceilings }\end{array}$ & $\begin{array}{c}\text { Secondary } \\
\text { market }\end{array}$ & $\begin{array}{c}\text { Presence of } \\
\text { third parties }\end{array}$ \\
\hline Belgium & $\begin{array}{c}\text { Open } \\
\text { season }\end{array}$ & UIOLI & no & yes & yes \\
\hline France & First come & UIOLI & no & yes & no \\
\hline
\end{tabular}

18 Users pay a tariff related to the number of slots they nominate. A slot includes unloading, storage and regasification capacity for 10,35 days for a vessel with $140.000 \mathrm{~m} 3$ of capacity. So the Belgium tariffs may be considered $100 \%$ capacity-related. 


\begin{tabular}{|l|c|c|c|c|c|}
\hline & first served & & & & no \\
\hline Italy & Merit order & UIOLI & no & yes & yes \\
\hline Spain & Merit order & yes & $\begin{array}{c}50 \% \text { of } \\
\text { total } \\
\text { capacity }\end{array}$ & n.a. & yes \\
\hline
\end{tabular}

Source: IEFE's elaboration on national authorities' data, 2006.

As it is possible to note from table 4, in every considered country there is a precise capacity allocation method. More in details France has chosen a "first come first served" mechanism while Italy and Spain have opted for a "priority order". In the UK and Belgium an open season for allocation of capacity takes place.

Every examined country has organised a secondary market for capacity allocation. This is to be claimed as positive considering that in this way also operators that have been previously excluded from the awarding procedure can get regasification capacity in case the original bidder should not use it.

Only Spain has foreseen a kind of antitrust ceiling in order to avoid a single operator to hold the total capacity available at a regasification plant: no one is in fact allowed to book more than $50 \%$ of total capacity.

As far as the presence on terminals of operators other than the vertically integrated incumbent company is concerned it is possible to observe that in Belgium, Spain and UK regasification capacity has been attributed to third parties.

Allocation methods adopted by European regulators seem, in the light of the above presented analysis, to be favourable to incumbents/terminal promoters (merit order or open season) or, at least, not able to lead to an efficient allocation of capacity (first come first served).

In such a circumstance the development of secondary markets and the proper use of UIOLI clauses seem to be of paramount importance.

In other words, there are many ways to allocate capacity between competing users; it is however essential that, whatever form of allocation is chosen, there has to be an effective secondary market and UIOLI regime to ensue that concerns about hoarding are addressed.

Of course, any method entails pros and cons under the competition point of view and the adoption of one procedure instead of another might be related to the consideration of different issues such as the protection of long-term supplies or security of supply.

Moreover a distinction between allocation of capacity on old or new investments should be made: the preferred form for the latter could be an open season or booking window where users submit their requirements. It is clear that the rules must be clear to all parties and not prevent new entrants from competing. It should also be considered that differing solutions may be appropriate even within one Member State. This has been recognised by the last Gas Directive (55/03) by the acceptance that exemptions may be granted under certain circumstances with different rules applying (Article 22). 
In fact it should be remembered that competition, independently from access rules, could be achieved also through new importing investments made by subjects different from national incumbents.

Despite the relative immaturity of market opening in Europe, recent years have in fact witnessed new large investments being realized by new suppliers willing to challenge former monopolistic companies in the future. This is a major benefit for the development of an internal energy market, the Security of Supply, through increased diversity of supplies and the development of effective competition in Europe.

Table 7: Request timing on LNG terminals in Europe: Belgium, France, Italy, Spain and UK

\begin{tabular}{|c|c|c|}
\hline \multirow{2}{*}{ Country } & \multicolumn{2}{|c|}{ Request Timing } \\
\hline & Firm Capacity & Spot Capacity \\
\hline Belgium & $\begin{array}{l}\text { Only users with long term } \\
\text { contracts with Fluxys can } \\
\text { nominate firm capacity. } \\
\text { Before the 20th day of month M-3, } \\
\text { the user of the LNG terminal } \\
\text { nominates the number of slots } \\
\text { that it is scheduling for the month } \\
\text { M. } \\
\text { Before the 20th day of month M-2, } \\
\text { the user of the LNG terminal } \\
\text { notifies the dates of the slots that } \\
\text { it has nominated. } \\
\text { On the 1st of month M-2 at the } \\
\text { latest, the user of the LNG } \\
\text { terminal must notify Fluxys LNG of } \\
\text { the slots that it does not intend to } \\
\text { use. Through this notification, the } \\
\text { user of the LNG terminal } \\
\text { authorises Fluxys LNG to sell those } \\
\text { unused slots. }\end{array}$ & $\begin{array}{l}\text { For the period preceding the first day } \\
\text { of month M-2, no specific measures are } \\
\text { taken by Fluxys LNG with regard to the } \\
\text { secondary market. } \\
\text { More than } 20 \text { days before the start } \\
\text { date of the slot, the user of the LNG } \\
\text { terminal can only sell its slots on the } \\
\text { secondary market in the form of full } \\
\text { slots (without breaking them down to } \\
\text { their constituent services). } \\
\text { From } 20 \text { days before the start date of } \\
\text { the slot, the user of the LNG terminal } \\
\text { can sell the different services that } \\
\text { constitute a slot separately on the } \\
\text { secondary market. }\end{array}$ \\
\hline France & $\begin{array}{l}\text { All the requests referring to the } \\
\text { thermal year " } t+1^{\prime \prime} \text { have to be } \\
\text { presented before } 15^{\text {th }} \text { October of } \\
\text { the thermal year " } t \text { ", otherwise } \\
\text { the regasification company may } \\
\text { refuse them. } \\
\text { Monthly nominations for month } m \\
\text { is set by the terminal operator on } \\
\text { the } 25^{\text {th }} \text { day of month } m-1 \text {, in line } \\
\text { with shippers' requests received } \\
\text { on the 20th day of month } m-1 \text { at } \\
\text { the latest. }\end{array}$ & $\begin{array}{l}\text { Spot capacity is allocated whenever } \\
\text { available through a communication on } \\
\text { Internet and it is subscribed to after } \\
\text { the 20th day of month } m-1 \text {. } \\
\text { Subscription is carried out based on } \\
\text { vacant slots in the monthly programme } \\
\text { at the time of subscription }\end{array}$ \\
\hline
\end{tabular}




\begin{tabular}{|c|c|c|}
\hline \multirow{2}{*}{ Country } & \multicolumn{2}{|c|}{ Request Timing } \\
\hline & Firm Capacity & Spot Capacity \\
\hline Italy & $\begin{array}{l}\text { At the beginning of each thermal } \\
\text { year, firm capacity is allocated for } \\
1 \text { year or a number of years, up to } \\
5 \text { years. } \\
\text { All the available capacity is firstly } \\
\text { allocated following the general } \\
\text { order of priority. } \\
\text { All requests have to be sent to } \\
\text { GNL Italia two years in advance. } \\
\text { Then, for each month, the } \\
\text { regasification company set up the } \\
\text { delivery schedule for the following } \\
\text { three months, basing its decision } \\
\text { on the users' proposals. For each } \\
\text { of the three months, the number } \\
\text { of unloads and the relating LNG } \\
\text { volumes are scheduled. Only for } \\
\text { the first month the precise } \\
\text { unloading date is set up. Other } \\
\text { details are defined in the } \\
\text { regasification code of each } \\
\text { receiving plant. }\end{array}$ & $\begin{array}{l}\text { Spot capacity may be allocated for the } \\
\text { month " } M \text { " to authorised operators if it } \\
\text { is available, due to delivery scheduling, } \\
\text { at the month " } M-1 \text { ". The possibility of } \\
\text { spot transactions depends on the } \\
\text { availability of the loading wharf for two } \\
\text { consecutive days and on the } \\
\text { availability of space in the storage } \\
\text { tanks. }\end{array}$ \\
\hline Spain & $\begin{array}{l}\text { Operators wishing to exercise their } \\
\text { right to access to regasification } \\
\text { plants must send a formal } \\
\text { capacity reservation request to the } \\
\text { owners of those installations } \\
\text { indicating their usage schedule } \\
\text { and calendar. }\end{array}$ & $\begin{array}{l}\text { The owners of a regasification plant } \\
\text { shall publish on a quarterly basis the } \\
\text { contracted and available capacity in } \\
\text { each one of their installations. They } \\
\text { shall make a distinction between } \\
\text { capacity assigned to access contracts } \\
\text { for a term or two or more years and } \\
\text { access contracts signed for a term of } \\
\text { less than two years. }\end{array}$ \\
\hline$U K$ & Contractual terms. & $\begin{array}{l}\text { In case of spare capacity, the } \\
\text { regasification company organize a } \\
\text { tender: the auction opens at } D-10 \\
\text { (that is to say ten days before the date } \\
\text { of possible cargo unloading) and closes } \\
\text { at } D-7 \text {, while the primary capacity } \\
\text { holder reserves the right to cancel the } \\
\text { auction at any time until gate closure } \\
\text { at } D-7 \text {. }\end{array}$ \\
\hline
\end{tabular}

Source: IEFE's elaboration on national authorities' data, 2006.

The request timing is very important in order to boost competition on the spot market. The nomination timing must be well designed, otherwise distortions may arise.

In fact, if terminal users can wait until a few days before the delivery day to nominate capacity and therefore release the unused capacity on the secondary market, then there won't be enough time to arrange spot cargoes, or it will be possible only from close locations. The consequence of such a system would be 
the technical impossibility for new operators to access capacity, with a detrimental outcome under the competition point of view.

On the other hand, if users are forced to nominate in advance, then incumbents may be favoured compared to new operators. In fact, new players may have difficulties in planning their deliveries because of lack of experience and of the restricted size of their portfolio which makes for them more difficult to forecast their customers' aggregated consumption profile.

So the choice of the request timing should mainly depend on the level of competition of the national market.

\section{New investments regulation}

Considering the two main goals of the liberalisation process, competition and security of supply, when deciding on access regulatory regimes to gas networks, a right balance has to be found between the promotion of new investments, leading to specific measures in favour of projects sponsors, and the necessity to ensure the development of competition, and, therefore, the need to ensure that newcomers have access to the liberalized market.

Several measures have already been implemented in some countries. The regulatory rules/constraints that may be imposed to the sponsor(s) to ensure that the new project will foster competition, and to contemporarily ensure its feasibility, are different:

- The diversification of shareholders;

- A minimum capacity share reserved for TPA under regulated tariffs;

- TPA with enhanced rate of return or specific TPA regime;

- A minimum capacity share reserved for short-term bookings.

\subsection{Diversification of shareholders}

Such a measure is implemented just in Italy and Spain but it actually regards solely the national transportation grid, and is not foreseen for new investments yet.

Its purpose is the one of granting, through a "splitted" ownership, that no one is able to control more than a determined share of equity (20\% currently in Italy, for instance). In this way the incumbent/promoter is believed to be unable to exert market power on the essential facility.

Such a measure could be helpful in granting a non-discriminatory access to the receiving terminal since the beginning of the send-out activity where an exemption is not granted, or, in case of application of Article 22 of the new Directive ${ }^{19}$, afterwards.

Ownership separation of the network would tend to mitigate this problem.

\section{2 Minimum capacity share reserved for TPA}

\footnotetext{
19 That foresees the possibility on a case by case basis to exempt a new plant from TPA legislation and to devolve part or the total capacity to the investment promoter.
} 
According to the need to favour new investments many countries have taken advantage of the provisions of the above mentioned Article 22.

In order to find the right balance between competition and security of supply it is however important that the exemption is granted just on a part of the new installed capacity, leaving the remainder available for third party access under regulated tariffs.

Table 8: Regulatory regime and Capacity allocation

\begin{tabular}{|l|l|l|}
\hline Country & Regulatory regime & Capacity allocation \\
\hline Belgium & Regulated TPA & Open season \\
\hline France & Exemption under art. 22 & $\begin{array}{l}\text { 90\% reserved to } \\
\text { sponsors/ 10\% } \\
\text { regulated TPA (FCFS) }\end{array}$ \\
\hline Italy & Exemption under art. 22 & $\begin{array}{l}80 \% \text { reserved to } \\
\text { sponsors/ 20\% for other } \\
\text { shippers }\end{array}$ \\
\hline Spain & Regulated TPA & FCFS \\
\hline UK & Exemption under art. 22 & Full TPA exemption \\
\hline
\end{tabular}

Source: GTE, 2006.

Among the considered countries, and according to the data in our possession, France, Italy and the UK have asked for different degrees of exemption.

In France the $90 \%$ of the new capacity is reserved to the sponsors of the project, while in the UK the exemption covers the whole capacity.

The percentage of reservation drops to $80 \%$ in Italy.

Capacity left for TPA amounts then to $10 \%$ and to $20 \%$ in France and Italy, respectively.

The following table highlights the "Pros and cons" of the default regulatory regime and the article 22 method.

Table 9: Pros and cons of the default regulatory regime and the article 22 method

\begin{tabular}{|c|c|c|}
\hline & Default regime & Article 22 \\
\hline PROS & $\begin{array}{l}\text { 1) Investors are on a "level } \\
\text { playing field with regard to } \\
\text { competition"; } \\
\text { 2) Rules are transparent and the } \\
\text { same for all market players; } \\
\text { 3) The default regime may be } \\
\text { adapted to promote new } \\
\text { investments for instance } \\
\text { costly/risky investments }\end{array}$ & $\begin{array}{l}\text { 1) Allows more tailored solutions and may } \\
\text { allow investments which would have not been } \\
\text { made in the regulatory regime, for instance } \\
\text { large and costly/risky projects } \\
\text { 2) Allows new players to enter the market } \\
\text { 3) There is a possibility to terminate with the }\end{array}$ \\
\hline
\end{tabular}

20 Recently capacity for third party has been made available on the French LNG system. Nevertheless the data in the table refer to the legislation in force at present. 


\begin{tabular}{|c|c|c|}
\hline & & exemptions in case of abuse of dominant position \\
\hline CONS & $\begin{array}{l}\text { The default regime may not be } \\
\text { adapted for some specific } \\
\text { investments }\end{array}$ & $\begin{array}{l}\text { 1) A level playing field between new projects is } \\
\text { more difficult to ensure. The coexistence of } \\
\text { infrastructures built under the default regime } \\
\text { and the exemptions of article } 22 \text { should not } \\
\text { create market distortions } \\
\text { 2) Need to ensure that the exemption does not } \\
\text { give market power to the investor } \\
\text { 3) Attention should be made to give room to } \\
\text { short term flows of gas } \\
\text { 4) Need from the sponsor to ask for an } \\
\text { authorization from the national regulatory } \\
\text { authorities and from the EU Commission which } \\
\text { burdens the process to assess applications } \\
\text { 5) Need to ensure that the article } 22 \\
\text { mechanism rightly address the concerns of the } \\
\text { sponsor which takes the risk and does not } \\
\text { threaten competition } \\
\text { 6) A priori, there is no transparency on tariffs } \\
\text { for the use of the infrastructure and flows }\end{array}$ \\
\hline
\end{tabular}

Source: IEFE, 2006.

\subsection{Enhanced rate of return and specific TPA regime}

The regulatory regime for new large gas investments can vary according to different approaches between:

- Standard regulated TPA (default regime as in Spain);

- Regulated TPA with an enhanced rate of return to compensate for higher risks, with in some cases multi annual tariffs (the enhanced rate of return may be considered on a case by-case basis);

- Specific TPA regime (as in Italy).

Table 10: Incentives for new investments

\begin{tabular}{|l|c|c|}
\hline Country & $\begin{array}{l}\text { Higher rate of return } \\
\text { for new projects }\end{array}$ & $\begin{array}{l}\text { Other measures to } \\
\text { incentive investments }\end{array}$ \\
\hline Belgium & Yes & No \\
\hline France & Yes & No \\
\hline Italy & Yes & $\begin{array}{l}\text { Free tariff setting for one } \\
\text { year for 20\% of capacity }\end{array}$ \\
\hline Spain & No & No \\
\hline UK & Yes & No \\
\hline Source
\end{tabular}

Source:GTE, 2006.

A higher rate of return for new projects is foreseen in all countries but Spain. This measure is usually granted on a case-by-case basis according to the 
existence of certain conditions such as contribution to security of supply, interoperability between national systems, push to competition or market integration.

In Italy a specific TPA regime is in operation. The promoter of the new terminal, besides the exemption on capacity, can freely set tariffs for the capacity left to third parties.

3.4 Minimum capacity share reserved for short-term bookings

Table 11: Measures fostering competition

\begin{tabular}{|l|c|c|}
\hline Country & $\begin{array}{c}\text { Minimum capacity } \\
\text { share for short term } \\
\text { bookings }\end{array}$ & $\begin{array}{c}\text { Other measures } \\
\text { fostering competition }\end{array}$ \\
\hline Belgium & No & No \\
\hline France & $10 \%$ & $\begin{array}{c}\text { No operator shall be } \\
\text { allowed more than } 2 / 3 \\
\text { of terminal capacity }\end{array}$ \\
\hline Italy & No & No \\
\hline Spain & $25 \%$ & $\begin{array}{c}\text { No more than } 50 \% \text { of } \\
\text { the short term capacity } \\
\text { can be booked by the } \\
\text { same shipper }\end{array}$ \\
\hline UK & No & No \\
\hline Sou
\end{tabular}

Source: GTE, 2006.

Finally there are countries in which a minimum capacity share for short term booking is reserved.

It is the case of France where capacity not reserved to sponsors must be used for spot transactions, and Spain where the minimum capacity share for short term booking rises to $25 \%$.

As far as other measures for fostering competition is concerned it is worth mentioning that in France no sponsor of a project is allowed to retain more than $2 / 3$ of installed capacity, and that in Spain no more than the $50 \%$ of the short term capacity can be booked by the same shipper.

\section{Conclusions}

In the presented analysis we have shown the potentiality of LNG in terms of contribution to the achievement of the liberalisation process targets. According to its minor specificity, compared to the pipeline transportation investment, LNG seems in fact to be able to lead to the enlargement of the natural gas supply side: a regasification terminal could receive cargoes from different supply sources, allowing the importer to choose its supplier according to the

${ }^{21}$ CRE Deliberation on the protocol between GdF and Total for existing terminals. 
competitiveness of the offered gas. In this way the bargaining power of importers would increase offsetting the decrease in contractual power that might stem from the fragmentation of the supply side down the European border, as a consequence of competition. Moreover LNG makes it possible to get to so far unexploited sources of export that, according to the distance from consumption markets, would not be reachable by pipe, further adding to supply diversification.

The infrastructural analysis regarding capacity allocation on terminals planned and under construction has also demonstrated that in the future several new importers will enter the European gas market.

Nevertheless LNG potentialities can be significantly affected/emphasised by regulation. The here provided regulatory overview showed that rules regarding access to regasification plants (tariffs and access conditions) and promotion of new investments differ widely across countries. The reason for this has to be sought in different policies regarding the issue of security of supply (incentives for new investments) and competition (refusal of exemption ex article 22 of the new Gas Directive).

In particular Spain and UK place themselves at the extremes.

The former has in fact opted for generalised TPA regime without foreseeing any merit order capacity allocation, or enhanced rate of return on new investments, while introducing several measures fostering competition such as antitrust ceilings on capacity booking and minimum capacity shares for short terms bookings. On the contrary UK has chosen complete TPA exemption and higher rate of returns on new receiving plants.

This demonstrated that security of supply and competition can receive different consideration within LNG regulation, and how these two issues could be inversely correlated generating a critical trade-off.

Nevertheless the aim of our paper was not the one of taking a stand on this point, expressing a value-preference among the two goals, but rather the one of highlighting how critical it is the role of regulation in finding a proper balance between them.

More particularly we believe that a clear policy should be implemented at the European Union level considering that market integration, which is one of the main goals of liberalisation, and the natural condition for the development of competition without harming security of supply, should occur both under a physical (grid interconnection) and regulatory (establishment of a common level playing field) point of view. 


\section{REFERENCES}

Ait-Laoussine N., 2003, "Europe's Security of Gas Supply: A Producer's Perspective", Presentation at Flame 2003, European Gas Conference, Amsterdam

Bartsch, U., 1998, "Financial Risks and Rewards in LNG Projects: Qatar, Oman, and Yemen", Oxford Institute for Energy Studies, Oxford

Balduzzi P., 2005, Lezioni di teoria delle aste

Bourdaire J-M., 2003, "The Growth of Natural Gas in Electricity: A New LNG Role for Supply and Flexibility", International Gas Union, 22ndWorld Gas Conference, Tokyo

BP, 2006, Energy Statistics

BP Magazine, "LNG", One 2004

Brattle Group, 2000, "Methodologies for establishing national and cross-border systems of pricing of access to the gas system in Europe", London

Brattle Group, C. Lapuerta, B. Moselle, 2002, "Convergence of non discriminatory tariffs and congestion management systems in the European Gas sector", London

Cayrade P., 2004, "Investments in Gas Pipelines and Liquefied Natural Gas Infrastructure", Nota di lavoro 114.2004, Fondazione ENI Enrico Mattei, Rome, available at:

http://www.feem.it/Feem/Pub/Publications/WPapers/default.htm (last visited September 21, 2006)

CEC (Commission of the European Communities), "Third-party access to Storage Facilities", Note on Directives 2003/54/EC and 2003/55/EC on the Internal Market in Electricity and Natural Gas, Brussels 
CEC, "Directive 2003/55/EC of the European Parliament and of the Council of 26 June 2003 Concerning Common Rules for the Internal Market in Natural Gas and Repealing Directive 98/30/EC", Official Journal of the European Union

CEC, "Guidelines for Good TPA Practice", revised version, Brussels

CEC, 2003, "Long Term gas Supply Security in an Enlarged Europe", Brussels

CEC "Green Paper: Towards a European Strategy for the Security of Energy Supply", Brussels

Cedigaz, "LNG Trade and Infrastructures", Rueil Malmaison: Institut Français du Pétrole

Cedigaz, "Towards the Creation of a Single European Gas Market", Rueil Malmaison: Institut Français du Pétrole

CEER (Council of European Energy Regulators), "The Development of Gas Hubs and Trading Centres in Europe"

CEER, 2003, "Recommendations on Implementation of Third-party access to Storage and Linepack"

CEER, 2002, "Establishing the Preferred Tariff Methodology for Intrastate, Cross-Border and Transit Flows in European Gas Markets", CEER Paper to the Madrid Forum

Cervini G., "L'intervento pubblico nelle essential facility: aspetti teorici e analisi istituzionale", in Concorrenza e Mercato, Milano

Chabrelie M.F., 2006, " Quel avenir pour le gaz en Europe", Cedigaz

CIEP, The Role of Liquefied Natural Gas (LNG) in the European Gas Market, The Hague

Clingendael International Energy Programme, 2003, "The role of LNG in the European Gas Market", The Hague 
Crew M.A., 2002, "Regulatory economics: twenty years of progress?", Journal of Regulatory Economics

CRS Report for Congress, 2006, "Liquefied Natural Gas (LNG) in U.S. Energy Policy: Infrastructure and Market Issues", Washington

Dailami, M., Hauswald, R., 2000, "Risk Shifting and Long-Term Contracts Evidence from the RasGas Project", World Bank Policy Research Working Paper 2469, Washington, D.C.

Deloitte, 2005, Resources News, August - September issue

Domah P. and Pollit M., 2001, "The Restructuring and Privatization of Electricity Distribution and Supply Businesses in England and Wales: a Social Cost-Benefit Analysis"

Dorigoni S., 2004, Il ruolo delle tariffe di trasporto del gas naturale nella liberalizzazione del mercato, Genova

D.C.N. Ejiroghene, 2002, "Are the changes in the LNG industry sufficient to support project financing of non-contracted ships? (unpublished LLM research paper submitted to CEPMLP, University of Dundee)

EIA, 2004, "Annual Energy Outlook", Washington

ENI Group and IFP, "Gate 2020 - Gas Advanced Technology for Europe at the year 2020", Study for the European Commission (DG TREN), Bruxelles

Eurogas, "Eurogas Response to Proposed Security of Natural Gas Supply Directive", Brussels

Eurogas, "Security of Gas Supplies, Markets, Principles and Actors", Brussels

Eurostat, 2006, General and Regional Statistics

Galbraith, J.K. 1952. American Capitalism: The Concept of Countervailing Power. Boston:

Houghton Mifflin.

Gautier A. and Manipushpak M., 2005, "Regulation of an Open Access Essential Facility" 
Gobbo F., Noce A., "Il settore del gas naturale: tra monopolio e concorrenza", in Grassini F.A., La concorrenza nei servizi di pubblica utilità, Bologna

GTE, "Security of Natural Gas Supply", Brussels

Hafner M., "Future natural gas supply options and supply costs for Europe", OME

Hallouche H., 2006, "The Gas Exporting Countries Forum: Is it really a Gas OPEC in the Making?", Oxford Institute for Energy Studies

Honoré A., 2006, "Future Natural Gas Demand in Europe", Oxford Institute for Energy Studies

IEA, 2005, Electricity Information

IEA, 2002, World Energy Outlook

IEA, 2004, World Energy Outlook

IEA, 2006, World Energy Outlook

IEA, 2003, IEA Statistics: Natural Gas Information, Paris

IEA, 2004, "Security of Gas Supply in Open Markets - LNG and Power at a Turning Point", OECD, Paris

IEA, 2002, "Flexibility in Natural Gas Supply and Demand", OECD, Paris

IEEJ, 2005, "LNG Supply and Demand in Asia Pacific and Atlantic Market"

Jensen Associates, "The future of gas transportation in the Middle East: Lng, Gtl and pipelines", A presentation to the annual conference of the Emirates Center for Strategic Studies and Research

Jensen J.T, February 2005,"Global LNG Markets - The Challenge in Meeting Forecast Growth", LNG Summit, Amsterdam 
Jensen J.T., 2003, "The LNG Revolution", Energy Journal of the International Association for Energy Economics

Jensen J.T., 2006, "The Development of a Global LNG Market", Oxford Institute for Energy Studies

Kahn A.E., "The Economics of Regulation: principles and institutions"

Katz M.,1983, "Nonuniforming Pricing, Output and Welfare under Monopoly", Review of Economic Studies

Kessides I., 2004 "Reforming Infrastructure: Privatization, Regulation and Competition", World Bank Policy Research Report, Oxford University Press

Lee H, 2005, "Dawning of a New Era, the LNG Story", J.F. Kennedy School of Government paper, Harvard University, Harvard, MA

LNG statistics Clarksons, 2005

Local Regulatory Authorities web-sites and direct inquires.

Maritime Business Strategies, List of the LNG Shipping Tankers at June 2006

Marzi G., Prosperetti L., Putzu E., 2001, "La regolazione dei servizi infrastrutturali", il Mulino

Morgan Stanley, 2005, "Financing LNG Projects", Center for Strategic Research report, London

Morita K., Ueda T., Nagasaka S. Dec. 2003, "Study of Changes in Patterns of LNG Tanker Operation", IEEJ, Tokyo

Morikawa T., 2004, "LNG Supply and Demand in Asia Pacific and Atlantic Markets", IEEJ, Tokyo

Oi W.Y., 1971 "A Disneyland Dilemma: Two Part Tariffs for a Mickey Mouse Monopoly", Quarterly Journal of Economics 
Oil and Gas Journal, Tulsa, Oklahoma, various issues

Osadebe, U. C., 2004, "What effect does the emerging spot market for LNG have on the financing of gas projects?", available at www.dundee.ac.uk/cepmlp/car/html/car8_article1.pdf (last visited September $21,2006)$

Project Finance International Yearbook 2002

Raskovich, A. 2003. Pivotal buyers and bargaining position. Journal of Industrial Economics 51, 405-426.

Rowe D., 2004, "LNG Market Overview", The Oxford Princeton Programme Simmons \& Company International, April 2005, "Liquefied Natural Gas"

Schmalensee R., 1981 "Monopolistic Two Part Pricing Arrangements", Bell Journal of Economics

Simmons\&Company International, 2005, "Liquefied Natural Gas", Integrated oil research

Snyder, C.M. 1999 Why do large buyers pay lower prices? Intense supplier competition.

Economics Letters 58, 205-209.

Spence A.M., 1977, "Nonlinear Prices and Welfare", Journal of Public Economics

Stern J., "Competition and liberalization in European gas markets. A diversity of models", The Royal Institute of International Affairs, Washington

Stern J., "Security of European Natural Gas Supplies: The Impact of Import Dependence and Liberalisation", Royal Institute of International Affairs, London

Tirole J., 1988, "The theory of industrial organisation", The MIT press

Torner A., 2004, "New Energy Technologies in the Natural Gas Sectors", IPP, Rice University 
Tveitness T., 2005, "Future Technological Challenges in LNG Shipping", LNG Journal-Norshipping

Vogelsgang I., 2002, "Incentive regulation and competition in public utility markets: a 20 years perspective", Journal of Regulatory Economics

World Gas Intelligence, New York, various issues

www.autorita.energia.it

www.ceer-eu.org

www.eia.doe.gov/emea/cabs/spain.html

www.ferc.gov

www.ogj.com/Ingobserver

www.projectfinancemagazine.com

www.world-register.org 